\title{
Opportunities Surrounding the Use of Sargassum Biomass as Precursor of Biogas, Bioethanol, and Biodiesel Production
}

\author{
Jorge Gabriel Orozco-González¹, Fernando Amador-Castro', Angela R. Gordillo-Sierra², \\ Tomás García-Cayuela ${ }^{1 *}$, Hal S. Alper ${ }^{2,3}$ and Danay Carrillo-Nieves ${ }^{1 *}$
}

${ }^{1}$ Tecnologico de Monterrey, Escuela de Ingenieria y Ciencias, Zapopan, Mexico, ${ }^{2}$ McKetta Department of Chemical Engineering, The University of Texas at Austin, Austin, TX, United States, ${ }^{3}$ Institute for Cellular and Molecular Biology, The University of Texas at Austin, Austin, TX, United States

OPEN ACCESS

Edited by:

El-Sayed Salama,

Lanzhou University, China

Reviewed by:

Wilson Thau Lym Yong, Universiti Malaysia Sabah, Malaysia Nadia Samak,

Institute of Process Engineering, Chinese Academy of Sciences (CAS),

China

*Correspondence: Tomás García-Cayuela tomasg@tec.mx

Danay Carrillo-Nieves danay.carrillo@tec.mx

Specialty section:

This article was submitted to Marine Biotechnology,

a section of the journal

Frontiers in Marine Science

Received: 07 October 2021 Accepted: 20 December 2021 Published: 11 January 2022

Citation:

Orozco-González JG, Amador-Castro F, Gordillo-Sierra AR,

García-Cayuela T, Alper HS and Carrillo-Nieves D (2022) Opportunities Surrounding the Use of Sargassum Biomass as Precursor of Biogas, Bioethanol, and Biodiesel Production. Front. Mar. Sci. 8:791054. doi: 10.3389/fmars.2021.791054
Climate change (along with other factors) has caused an increase in the proliferation of brown algal mats floating freely along the Atlantic Ocean since 2011. These brown algae mats are composed of sea plants from the Sargassum genus. The gargantuan agglomeration of biomass flows alongside currents and lands in beaches belonging to the Eastern coasts of the Mexican Caribbean and several other countries in the region. These events, dubbed golden tides, harm the local economy and environment. Current elimination approaches involve the mechanical harvesting of the Sargassum and ultimate landfill disposal. However, explorations into the commercial application of other brown algae have elucidated the potential of Sargassum as a feedstock for valorization. This review informs the trends, challenges, and opportunities presented by the coastal invasion of this biomass. Primarily, the potential use of this material is as a precursor in biorefineries where multiple value-added products are generated concurrent with the ultimate production of biofuels.

\footnotetext{
Keywords: Sargassum seaweed, biofuel, biorefinery, bioconversion, green technology, green fuels, biomass valorization
}

\section{INTRODUCTION}

Sargassum is a genus of brown macro-algae that clusters into long algal mats that drift on the ocean surface and move along with ocean currents (Thompson et al., 2020b). The frequency, range, and magnitude of encroachment of Sargassum onto coasts around the world have increased dramatically in recent years (Milledge and Harvey, 2016). Also known as "golden tides," these seasonal seaweed strandings are linked mainly to climate change and excessive nutrient loading (Thompson et al., 2020b). Anomalous nutrient discharge from the Amazon River related to deforestation and changes in deposition patterns of African dust from the Sahara Desert has been related to the establishment and recurrence of Sargassum blooms. Changes in wind currents attributed to the 2009-2010 winter negative North Atlantic Oscillation (NAO) caused a redistribution of pelagic Sargassum along the Atlantic. This event served as the starting point for the aggregation of these algae along the Inter-Tropical Convergence Zone (ITCZ) (Johns et al., 2020). 
Due to massive inundation events, Sargassum has become one of the most significant threats to the integrity of marine ecosystems. Sargassum algae begin to decay soon after reaching shallow waters and beaches. Moldering algae remove oxygen from surrounding water and release large amounts of toxic gases like hydrogen sulfide and ammonia. This results in the mortality of fish and other marine organisms and has increased concerns about human exposure to pernicious gases. Indeed, this has had a detrimental effect on affected countries' fishing and tourism industries (Davis et al., 2021).

Pelagic Sargassum has two large proliferation regions: the Sargasso Sea located east of the Florida Straits, where these algae grow during spring and summer months, and the North Equatorial Recirculation Region (NERR) (Figure 1), located northeast of Brazil (Thompson et al., 2020b). The growth of pelagic Sargassum in the NERR is considered responsible for the lofty levels of algal inundation in the Caribbean over the last few years (Thompson et al., 2020b). The brown algae aggregate in large patches in the ITCZ from March through September (Thompson et al., 2020b).

Sargassum casting ashore in large quantities has become recurrent in some African countries and the Greater Caribbean coast since 2011 (García-Sánchez et al., 2020). In particular, peak deposits in the Mexican Caribbean reached record highs in September 2015, May 2018 and continue to expand into 2021 (García-Sánchez et al., 2020; Thompson et al., 2021). In 2015, this amounted to approximately 10,000 wet tons per day (Wang and $\mathrm{Hu}, 2016)$. Mexico, in particular, is one of a handful of countries that has received compelling and problematic amounts of Sargassum sp. on its shores (Figure 1). The problem has reached significant proportions, costing the city of Cancún, Mexico, \$36.7 million on beach cleanup in 2019 alone (BBC, 2019).

Sargassum species registered to have arrived in the Mexican Caribbean between September and November of 2018 are Sargassum fluitans morph III (65\% of total), Sargassum natans morph I (15\% of total), and Sargassum natans morph VIII (4\% of total). Figure 2 depicts the general appearance of the stems, spines, and leaves of these different pelagic species of Sargassum. As of 2021, pelagic Sargassum landings in the Caribbean continue to be mainly comprised of S. fluitans and S. natans (Thompson et al., 2021).

Since Sargassum landings represent a far-reaching threat to abounding coastal communities and environments, especially in Mexico, researchers have been focusing on effective ways to valorize this feedstock and revamp it into value-added compounds for varied industries. Among the numerous applications of Sargassum biomass that have been reported, special attention has been placed toward agricultural products, cosmeceuticals, pharmaceuticals, and clean energy (AmadorCastro et al., 2021). Of particular interest, biofuels obtained from pelagic Sargassum could represent a green energy alternative to the highly unsustainable and environmentally detrimental consumption of fossil fuels (del Río et al., 2019; Savage et al., 2020).

Thompson et al. (2019, 2020b, 2021) and Abomohra et al. (2018, 2021) have proposed pathways for producing biofuels from algal biomass at a laboratory scale. Currently, industrialscale biorefineries are not a reality converting pelagic Sargassum biomass. A chief obstacle when valorizing seaweeds is that extraction of a single molecule or compound is often not profitable unless that molecule has an exceptionally high market value. An integrated process in which the bioethanol or biogas formed from Sargassum fermentation is contemporaneously produced with another value-added compound, like alginate, could make the process more appealing. The purpose of this review is to discuss the trends and challenges of converting Sargassum biomass into green biofuels such as biogas, bioethanol, and biodiesel, pointing toward biorefinery strategies aimed at extracting high-value intermediate products. Important information on how algae composition, recollection strategies, and pretreatment procedures impact Sargassum biomass conversion is presented.

Because of a lack of research and information found in the literature, pelagic Sargassum throughout the review will also be compared to other species of Sargassum. Although not having more studies and data on S. fluitans and S. natans is not ideal, most brown algae are similar in many aspects and can serve as a starting point for comparison and inquiry. Many of the processes described during this review could also be applied to other species of brown algae, but pelagic Sargassum is of great interest because it arrives in such large volumes to many countries and has a realistic potential of becoming a biomass substrate for the biofuel industry in years to come.

\section{SARGASSUM COMPOSITION AND BIOMASS COLLECTION PROCESS}

\section{Sargassum Composition to Obtain Added-Value Products Before Biofuel Production}

Sargassum algae are composed of water, organic compounds, and possibly toxic trace elements (Davis et al., 2021). The main composition of Sargassum sp. recollected in different regions worldwide is shown in Table 1 . The composition between different species of the same brown algae genus does not show significant variations.

Encrusted Bryozoa marine organisms are present in most Sargassum samples, and it is not economically feasible nor viable to remove them. The exoskeleton of bryozoans imparts an additional calcium carbonate source in many algae mats (Davis et al., 2021). Seaweeds like Sargassum are also associated with microbiota, especially from phylum Proteobacteria and Bacteroidetes, which fluctuate depending on the time of the year, propagation space, and whether the algae is healthy or stressed (Serebryakova et al., 2018).

As seen in Table 1, S. natans morphotype I and S. fluitans have singularly similar calcium carbonate, moisture, and organic matter content. Ash content is very similar between morphotype IV and morphotype I of $S$. natans, with $S$. fluitans char content being 3\% higher (Davis et al., 2021). All members of pelagic Sargassum contain similar trace quantities of metals 


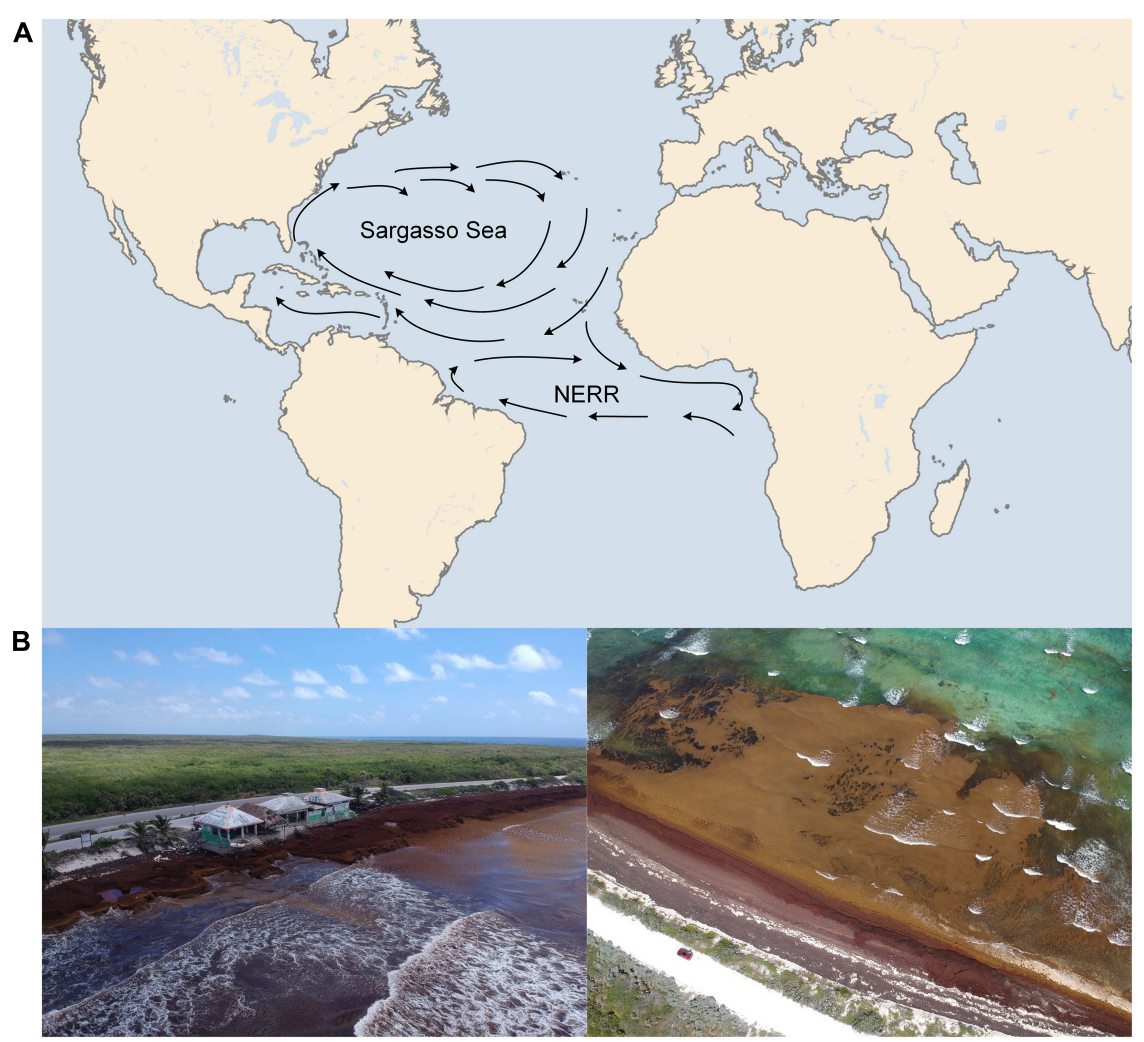

FIGURE 1 | (A) Map of the two main regions of Sargassum proliferation. (B) Aerial views of Sargassum beaching in the Mexican state of Quintana Roo (20²5' $26.2^{\prime \prime} \mathrm{N} 86^{\circ} 50^{\prime} 34.1^{\prime \prime} \mathrm{W}$ ), a state which has been economically and environmentally affected by the arrival of Sargassum in a very profound manner (September 2019). Pelagic Sargassum proliferation is an event exclusive to the Atlantic Ocean and Caribbean Sea. Other oceans and seas around the world are home to varied species of algae which have adapted to the local conditions for survival.

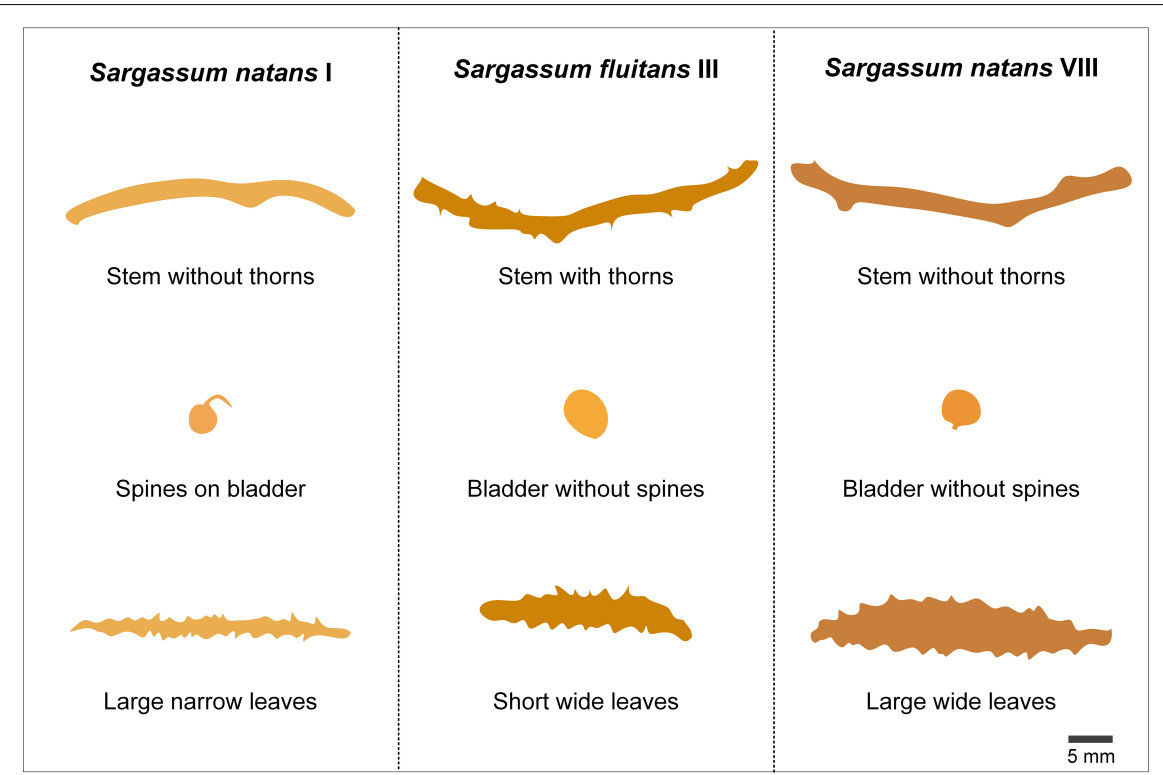

FIGURE 2 | Visual representation of the tangible differences between S. fluitans and $S$. natans. The morphological differences between these two species can be useful for researchers seeking to sort biomass collected by species. In the future, some species of Sargassum could be determined to be more useful for a specific purpose, this is why it is important to notice the differences between the two main pelagic brown algae. 
TABLE 1 | Differences in the Sargassum sp. composition from different collection sites.

\begin{tabular}{|c|c|c|c|}
\hline $\begin{array}{l}\text { Collection } \\
\text { sites }\end{array}$ & Parameter & $\%$ & References \\
\hline \multirow[t]{6}{*}{ Portugal } & $\begin{array}{l}\text { Total solids (TS)-1 } \\
\text { Sargassum sp. }\end{array}$ & $89.5 \pm 0.3^{\star}$ & $\begin{array}{l}\text { Oliveira et al., } \\
2015\end{array}$ \\
\hline & $\begin{array}{l}\text { Volatile solids (VS)_² } \\
\text { Sargassum sp. }\end{array}$ & $53.8 \pm 0.8^{\star \star}$ & \\
\hline & $\begin{array}{l}\text { Protein- }{ }^{3} \\
\text { Sargassum sp. }\end{array}$ & $23.6 \pm 0.5^{\star \star}$ & \\
\hline & $\begin{array}{l}\text { Lipid- }^{3} \\
\text { Sargassum sp. }\end{array}$ & $2.73 \pm 0.05^{\star \star}$ & \\
\hline & $\begin{array}{l}\text { Xylan (carbohydrates)- }{ }^{3} \\
\text { Sargassum sp. }\end{array}$ & $11.7 \pm 1.3^{\star \star}$ & \\
\hline & $\begin{array}{l}\text { Glucan (carbohydrates)- }{ }^{3} \\
\text { Sargassum sp. }\end{array}$ & $32.9 \pm 2.6^{\star \star}$ & \\
\hline \multirow[t]{4}{*}{ Jamaica } & $\begin{array}{l}\text { Calcium carbonate-4 } \\
\text { S. natans } 1^{A} \\
\text { S. fluitans }{ }^{B}\end{array}$ & $\begin{array}{l}9.49 \pm 1.75^{A \text { A* }} \\
10.75 \pm 1.10^{B \text { }}\end{array}$ & $\begin{array}{l}\text { Davis et al., } \\
2021\end{array}$ \\
\hline & $\begin{array}{l}\text { Moisture content-4 } \\
\text { S. natans }\left.\right|^{A} \\
\text { S. fluitans }{ }^{B}\end{array}$ & $\begin{array}{l}7.61 \pm 0.31^{A \star \star \star} \\
7.25 \pm 0.42^{B \star \star \star}\end{array}$ & \\
\hline & $\begin{array}{l}\text { Organic matter content- } 4 \\
\text { S. natans }\left.\right|^{A} \\
\text { S. fluitans }{ }^{B}\end{array}$ & $\begin{array}{l}29.11 \pm 1.32^{A \star \star \star} \\
28.86 \pm 0.40^{B \star \star \star}\end{array}$ & \\
\hline & $\begin{array}{l}\text { Ash (char) content-4 } \\
\text { S. natans }\left.\right|^{A} \\
\text { S. fluitans }{ }^{B}\end{array}$ & $\begin{array}{l}35.16 \pm 6.05^{A \star \star \star} \\
39.63 \pm 1.34^{B \star \star \star}\end{array}$ & \\
\hline \multirow[t]{2}{*}{ Mexico } & $\begin{array}{l}\text { Lipid- } \\
\text { Pelagic Sargassum }\end{array}$ & $3.3 \pm 0.12^{\star \star \star \star}$ & $\begin{array}{l}\text { Saldarriaga- } \\
\text { Hernandez } \\
\text { et al., } 2021\end{array}$ \\
\hline & $\begin{array}{l}\text { Moisture content-Pelagic } \\
\text { Sargassum }\end{array}$ & $5.4 \pm 0.5^{\star \star \star \star}$ & \\
\hline \multirow[t]{3}{*}{ Spain $^{5}$} & $\begin{array}{l}\text { Protein- Sargassum } \\
\text { muticum }\end{array}$ & $1.6 \pm 0.1^{\star \star \star \star \star}$ & $\begin{array}{l}\text { González- } \\
\text { Ballesteros } \\
\text { et al., } 2021\end{array}$ \\
\hline & $\begin{array}{l}\text { Xylan + Galactose + } \\
\text { Mannose- Sargassum } \\
\text { muticum }\end{array}$ & $8.4 \pm 0.2^{\star \star \star \star \star}$ & \\
\hline & $\begin{array}{l}\text { Fucan (carbohydrates)- } \\
\text { Sargassum muticum }\end{array}$ & $8.8 \pm 0.1^{\star \star \star \star \star}$ & \\
\hline China $^{6}$ & $\begin{array}{l}\text { Total sugar content- } \\
\text { Sargassum henslowianum }\end{array}$ & $\begin{array}{l}61.1 \text { (SHAP-1) } 45.8 \\
\text { (SHAP-2) }\end{array}$ & $\begin{array}{l}\text { Sun et al., } \\
2020\end{array}$ \\
\hline
\end{tabular}

${ }^{1}$ Percentage from whole biomass.

${ }^{2}$ Percentage from total solids.

${ }^{3}$ Percentage from volatile solids (\% VS).

${ }^{4}$ Percentage from whole weight.

${ }^{5}$ Percentage after $4 \mathrm{~h}$ of extraction at $40^{\circ} \mathrm{C}$.

${ }^{6}$ SHAP-1 and SHAP-2 are purified fucoidans, a result of extractions, separations, and purifications done by the authors.

*Percentage after seaweed has dried at ambient temperature.

**Note that this value is from Sargassum sp., not pelagic Sargassum.

${ }^{* * *}$ Content average from a weight loss curve.

****Dried biomass (\%DW) from May through September 2019.

${ }^{* * * * *}$ Composition of extracts.

A S. natans I.

${ }^{B}$ S. fluitans.

like $\mathrm{Na}, \mathrm{Mg}, \mathrm{Al}, \mathrm{K}, \mathrm{Ca}, \mathrm{Cr}$ and $\mathrm{Fe}$. The scale for these trace elements goes from tens to thousands of $\mu \mathrm{g} / \mathrm{g}$ of dry weight (DW) biomass (Davis et al., 2021). Despite the low trace metal content, this metric requires monitoring if the Sargassum is to be used as a source of food for animals or humans.
Arsenic levels for $S$. natans morphotype I $(64.91 \pm 0.61 \mu \mathrm{g} / \mathrm{g}$ DW), S. natans morphotype VIII $(60.30 \pm 0.34 \mu \mathrm{g} / \mathrm{g} \mathrm{DW}$; $p=0.031)$, and $S$. fluitans $(58.32 \pm 2.29 \mu \mathrm{g} / \mathrm{g} \mathrm{DW} ; p=0.009)$ are important in terms of toxicity if the biomass is to be used as a soil enhancer and seaweed meal (Alzate-Gaviria et al., 2021). Phenolic compounds, namely phlorotannins, can be employed in functional foods, nutraceuticals, cosmetics, and pharmaceuticals (Davis et al., 2021).

Alzate-Gaviria et al. (2021) discovered that both S. natans and $S$. fluitans produce small quantities of lignin-like compounds as part of a second cell wall in response to stress variables like extreme heat and UV-light; stressors that can be mainly attributed to climate change. This phenomenon is not exclusive to algae, as environmental stressors are critical modulators of lignin biosynthesis genes in terrestrial plants (Moura et al., 2010). While pelagic Sargassum has been disclosed to contain negligible amounts of "lignin-like" compounds in its cell wall, the presence of true lignin in the Sargassum genus has not been confirmed. It is likely a function of the environment (Alzate-Gaviria et al., 2021). The low content of "lignin-like" compounds makes these algae ideal for biofuel production, as lignin is a customarily recalcitrant material that makes biodegradability difficult without pretreatment (Oliveira et al., 2015; Thompson et al., 2020b).

The main brown algal cell wall polysaccharide in Sargassum is alginate, a valuable hydrocolloid that accounts for up to $40 \%$ of its dry weight (Jung et al., 2013). Alginate is water-soluble, biodegradable, non-toxic, and non-irritant. It is composed of linear binary copolymers of $(1,4)$-linked $\beta$-D-mannuronic acid (M) and $\alpha$-L-guluronic acid (G) monomers. Sodium alginate is currently broadly used in the biomedical, cosmetic, textile, pharmaceutical, and food industries. Previous uses are due to its rheological properties, biodegradability, and ability to generate films (Hasnain et al., 2020; Chen et al., 2021). There is also a growing interest in using alginate as a low-priced protein source, smart small molecule delivery vehicles, films for bioremediation of heavy metal ions, and biomaterials for tissue reconstruction (Mohammed et al., 2020). As such, extraction of this alginate can be an important source of a value-added product from Sargassum that would improve the economics of biorefinery conversion.

The extraction of sodium alginate has been examined in the literature. Mohammed et al. (2020) achieved a 28\% crude yield after two extraction stages and a purity of $92 \%$ for sodium alginate extracted from Sargassum seaweed in the Caribbean. Ardalan et al. (2018) concluded that sodium alginate yield obtained from algae harvested during the summer was $9 \%$ higher (as compared to the winter harvest). The team worked with Sargassum angustifolium and unveiled that alginate extraction acted as a pretreatment of sorts for bioethanol production, yielding better results than fermentation that used the raw biomass directly. Flórez-Fernández et al. (2021) worked with Sargassum muticum and concluded that alginate-free Sargassum showed better susceptibility to anaerobic digestion than raw algae. Fenoradosoa et al. (2010) highlighted the relevance of the ratio between $\beta$-D-mannuronic acid and $\alpha$-L-guluronic acid $(\mathrm{M} / \mathrm{G})$ in alginate. Analysis using Nuclear Magnetic Resonance (NMR), Fourier Transform Infrared Spectroscopy (FTIR), and High-performance anion-exchange chromatography (HPAEC) 
can be used to determine the $\mathrm{M} / \mathrm{G}$ ratio, which influences the properties of alginate gels (Fenoradosoa et al., 2010).

The important divergence between microalgal substrates and macroalgal sources lies within the parameters that microalgae undertake cultivation and harvesting, whereas macroalgae are more practically gathered from natural sources (Siddiki et al., 2022). Microscopic marine plants can be multiplied from a sole cell. Macroalgae are readily available for the collection so that growth from spawn is not as scalable outside natural hydrographic biomes. Finally, the employment of microalgae as a biofuel resource is at the outset due to low productivity and high production expenditures (Brar et al., 2021).

\section{Collection of Pelagic Sargassum}

Sargassum is often garnered from shallow waters (MonroyVelázquez et al., 2019) or, more regularly, beach sites (Oliveira et al., 2015). It is recommended that pelagic Sargassum be garnered while it is still at sea, preferably near the shore, to prevent a negative visual impact on the waterfront and the unpleasant and detrimental smell produced by decomposing leachates and organic matter. Dakatso (2021) proposed that the best strategy is to collect the Sargassum in large quantities using variable-sized nets (to avoid killing local marine fauna) at reef lagoons, shallow waters, or high seas. Following collection, transferring Sargassum to freshwater is advised to induce osmotic shock and allow motile fauna to detach from the algae (Monroy-Velázquez et al., 2019). Recollection of rainwater on big containers is an eco-friendly option. Encrusted epiphytes can then be removed with the help of tweezers (Gouvêa et al., 2020). Pelagic Sargassum should then be allowed to dry at ambient temperature for several days under sunlight or in ovens at approximately $60^{\circ} \mathrm{C}$ for $8 \mathrm{~h}$. For biofuel applications, drying and milling the biomass is advised (Oliveira et al., 2015). This increases the surface area available for enzymatic hydrolysis and other processes and thus results in more efficient breaking down of structures release compounds/simple sugars. Mexican companies such as Alquimar (2019) and Dakatso (2021) aim to valorize Sargassum into high-added value products. However, even though research is being conducted on the production of biofuels from Sargassum, there are no companies currently probing this at a commercial scale (Tapia-Tussell et al., 2018).

\section{SARGASSUM PRETREATMENT METHODS}

The complexity of the cell wall of Sargassum brown algae requires a pretreatment step prior to anaerobic digestion or another microbial valorization. Chemical hydrolysis, vapor explosion, and biological pretreatments are some of the options reported for algal biomass. Borines et al. (2013) employed a high temperature and dilute acid pretreatment via which demonstrated an increase in the exposed internal structure of the pretreated Sargassum by scanning electron micrograph analysis. Posterior enzymatic hydrolysis using $50 \mathrm{FPU}$ cellulase/g Sargassum incubated at $50^{\circ} \mathrm{C}$, and $100 \mathrm{rpm}$ for $96 \mathrm{~h}$ showed a surge in the amount of glucose released (around $30 \mathrm{mg} / \mathrm{g}$ Sargassum) as compared to untreated Sargassum (Borines et al., 2013). Yuhendra et al. (2021) evaluated three types of pretreatments in Sargassum fulvellum for anaerobic digestion: acid pretreatment with $\mathrm{HCl}$; alkaline pretreatment with $\mathrm{NaOH}$; and biological treatment with Viscamyl ${ }^{\mathrm{TM}}$ flow cellulase enzyme. Enzyme-pretreated macroalgae reduced methane yield by $9.49 \%$ compared to the non-treated digester, in which finely milled biomass was left to decompose through hydrolysis of anaerobic microbes alone. While the study concluded that fine milling and rehydration are effective at exposing biomass contents, a contraction in biogas yields for all digesters was perceived when integrating chemical and mechanical pretreatments, as well as biological treatment (Yuhendra et al., 2021).

Basic hydrolysis is used in bioethanol production from terrestrial biomass. However, its appliance is not widely employed with brown algal sources (Tadesse and Luque, 2011; Ardalan et al., 2018; Savage et al., 2020). Basic hydrolysis relies on using basic solvents to realize the cleavage of ether linkages in lignin and ester linkages between lignin and hemicellulose, resulting in lignin removal (An et al., 2014). Reports of increased ethanol yield from alginate-free Sargassum using a method of alginate removal with alkaline solution (Flórez-Fernández et al., 2021) hint at the possibility that the alginate extraction process acts as an alkaline pretreatment step and thus enhances bioethanol production.

Hydrothermal pretreatment has been shown to boost the efficiency of seaweed degradation and bioavailability for assimilation by microorganisms (Thompson et al., 2020a). Hydrothermal pretreatment was examined for increasing biogas yield from Sargassum. Authors reported that soluble chemical oxygen demand yield increases by $237 \%$, compared to untreated biomass, during anaerobic digestion (Thompson et al., 2020a); this may be due to an increment in available digestible substrates derived from hydrothermal pretreatment. Furthermore, the slurry formed in hydrothermal pretreatment allows for better movement and distribution of microbes within the media compared to solid biomass. Pretreatments that produce biomass with adequate viscosity and water content may culminate in improved biofuel production.

Ionic liquids (ILs) are receiving attention as efficient and environmentally benign novel processes. ILs can dissolve copious amounts of cellulose under considerably mild conditions (in comparison to the harsh conditions of hydrothermal pretreatment). The feasibility of recovering the used ILs makes them alluring (Tadesse and Luque, 2011). A group of scientists used the ionic liquid 1-n-butyl-3-methylimidazolium chloride [(BMIM)Cl], followed by acid-catalyzed hydrolysis to treat three species of brown algae (one belonging to the Sargassum genus) and found that 15.5-29.4 wt.\% sugars can be recovered using this process (Malihan et al., 2012). As an additional example, Ravanal et al. (2016) pretreated the brown algae Macrocystis pyrifera with $2 \%$ vol. sulfuric acid for the discharge of glucose after enzymatic saccharification. "Green solvents" with the ionic liquids DBU-MEA-SO2-SIL and [DBNH][OAc] were used to liberate uronic acid in the saccharification step. Dilute acid pretreatment, followed by saccharification of cellulose with a mixture of cellulases at $\mathrm{pH} 5.2$ for $4 \mathrm{~h}$ at $50^{\circ} \mathrm{C}$ and saccharification of alginate with the enzyme lyase/oligo alginate lyase at $\mathrm{pH}$ 
7.5 for $2 \mathrm{~h}$ at $37^{\circ} \mathrm{C}$ were the evaluated pretreatment methods (Ravanal et al., 2016).

Autohydrolysis is deemed as an eco-friendly pretreatment that results in a solid phase with high enzymatic susceptibility and a liquid phase rich in oligosaccharides (Rostro et al., 2014). In autohydrolysis, the reaction is only catalyzed by hydronium ions and organic acids, without including any other catalyst. Nonisothermal autohydrolysis pretreatment was used by del Río et al. (2019) to prepare S. muticum (similar to pelagic Sargassum) for enzymatic hydrolysis. The raw material was mixed with water at high temperatures, ranging from $130-180^{\circ} \mathrm{C}$, depending on the desired severity. del Río et al. (2019) discovered that glucan could almost be retained entirely in the solid phase by using this pretreatment, which makes the process more enticing to researchers interested in using the solid phase for further processing and subsequent processing fermentation.

High-pressure technology pretreatment is an effective alternative that only uses heated water at high pressures. Although the cost of high-pressure equipment must be considered, this pretreatment is a worthwhile option that might be suitable for high-scale production in future biorefineries. Aparicio et al. (2021) evaluated the breaking capacity of the Sargassum sp. polysaccharides applying high-pressure pretreatment $\left(3.75-11.54\right.$ bar) at $190^{\circ} \mathrm{C}$ and a residence time of $50 \mathrm{~min}$. They reached a conversion yield of $92.12 \%$ of pretreated Sargassum and $76.23 \%$ of glucose to bioethanol. Any pretreatment above that does not utilize acids or compounds detrimental to the environment in their manufacturing is recommended for biogas, bioethanol, or biodiesel production. Hydrothermal pretreatment and high-pressure technology are highly endorsed. The following chapters will discuss the production of biogas, bioethanol, and biodiesel using Sargassum as substrate. The schematic for these processes is presented in Figure 3.

\section{SARGASSUM FOR BIOGAS PRODUCTION}

Anaerobic digestion is considered mature and efficient biotechnology for carbon source recovery and remediation from bioprocess residues (Thompson et al., 2020a). In this scheme, biogas is the main output of anaerobic digestion that can be used as a renewable energy source. Biomass resources such as food waste, municipal sewage wastewater, sewage, industrial organic effluents, energy crops, and agriculture residues have been successfully transformed to biogas by anaerobic digestion processes (Xue et al., 2020). In addition to biogas, a digestate with bio-fertilizer potential is generated from these waste-to-energy processes (Thompson et al., 2020a).

Macroalgae have been proven to be an excellent candidate feedstock for bio-energy production because of their rich polysaccharide and negligible lignin-like compounds (Montingelli et al., 2015). From this particular viewpoint, Sargassum is a promising alternative for third-generation biofuel feedstock (Kim et al., 2013; Xue et al., 2020). The fact that pelagic Sargassum has such poor lignin content means the conversion process can be more cost-effective and less time-consuming since lignin is hard to remove and pretreatment for its removal is often severe and expensive. A study with brown algae from Algeria (Posidonia oceanica) suggests that this algae biomass must undergo an extra step to delignify and leave the desired cellulose fibers exposed for a more efficient bioconversion (Tarchoun et al., 2019), a step that is not used in studies done with pelagic Sargassum. This represents an area of opportunity in the field of algal research, as there have not been enough studies as of now to evaluate the feasibility of use of pelagic Sargassum for biogas production.

Thompson et al. (2021) adjudged that pelagic Sargassum from the Caribbean can be used for optimized biogas production when using hydrothermal pretreatment coupled with anaerobic codigestion with food waste. Food waste was mainly composed of noodles, bread and rice, vegetables, meat, coffee, tea, fruits (24.8\%), and eggshells in the study. The composition of the biogas obtained will diverge depending on the pretreatment applied prior to digestion. Hydrothermal pretreatment on Sargassum biomass reduced the presence of hydrogen sulfide $\left(\mathrm{H}_{2} \mathrm{~S}\right)$ in biogas from 3 to $1 \%$, relative to the untreated biomass (Thompson et al., 2020a). In a posterior project, Thompson et al. (2019) studied the digestion times of Caribbean pelagic Sargassum and achieved maximum biogas recovery $(116.72 \pm 2.14 \mathrm{~mL} / \mathrm{g}$ VS $)$ within the first 5 days of digestion due to the absence of lag-phase time for methane production.

Some studies suggest there are ways to increase methane and/or carbon dioxide yields, making the process more efficient. Zaidi et al. (2021) studied biogas production using green algae from China along with nickel nanoparticles (Ni NPs) to attempt to increase biogas output, since NPs can weaken cell wall structures and cause some substrates (like certain carbohydrates) to be more readily available. Their results demonstrated that the best yield was attained using $1 \mathrm{mg}$ of Ni NPs per liter of the mixture. It is noteworthy to mention that green algae are different from brown algae in many aspects; therefore, adjoining nickel nanoparticles might not work for increasing the yield of biogas production in a process with pelagic Sargassum as biological waste. Oliveira et al. (2015) conducted a study with more relevant findings regarding biogas production using the Sargassum genus, although pelagic Sargassum specifically was not mentioned. Methane production rate increased 38\% when using glycerol as co-substrate and $19 \%$ when using waste frying oil as cosubstrate.

\section{SARGASSUM FOR BIOETHANOL PRODUCTION}

Algae capable of accumulating high starch/cellulose can serve as an excellent substitute for food crops feedstocks for bioethanol production (John et al., 2011). Furthermore, Sargassum is rich in hemicellulose. The first stage in bioethanol production is biomass pretreatment, as discussed in section "Sargassum Pretreatment Methods." Subsequently, enzymatic hydrolysis is exerted to break down polysaccharides into monomers, 


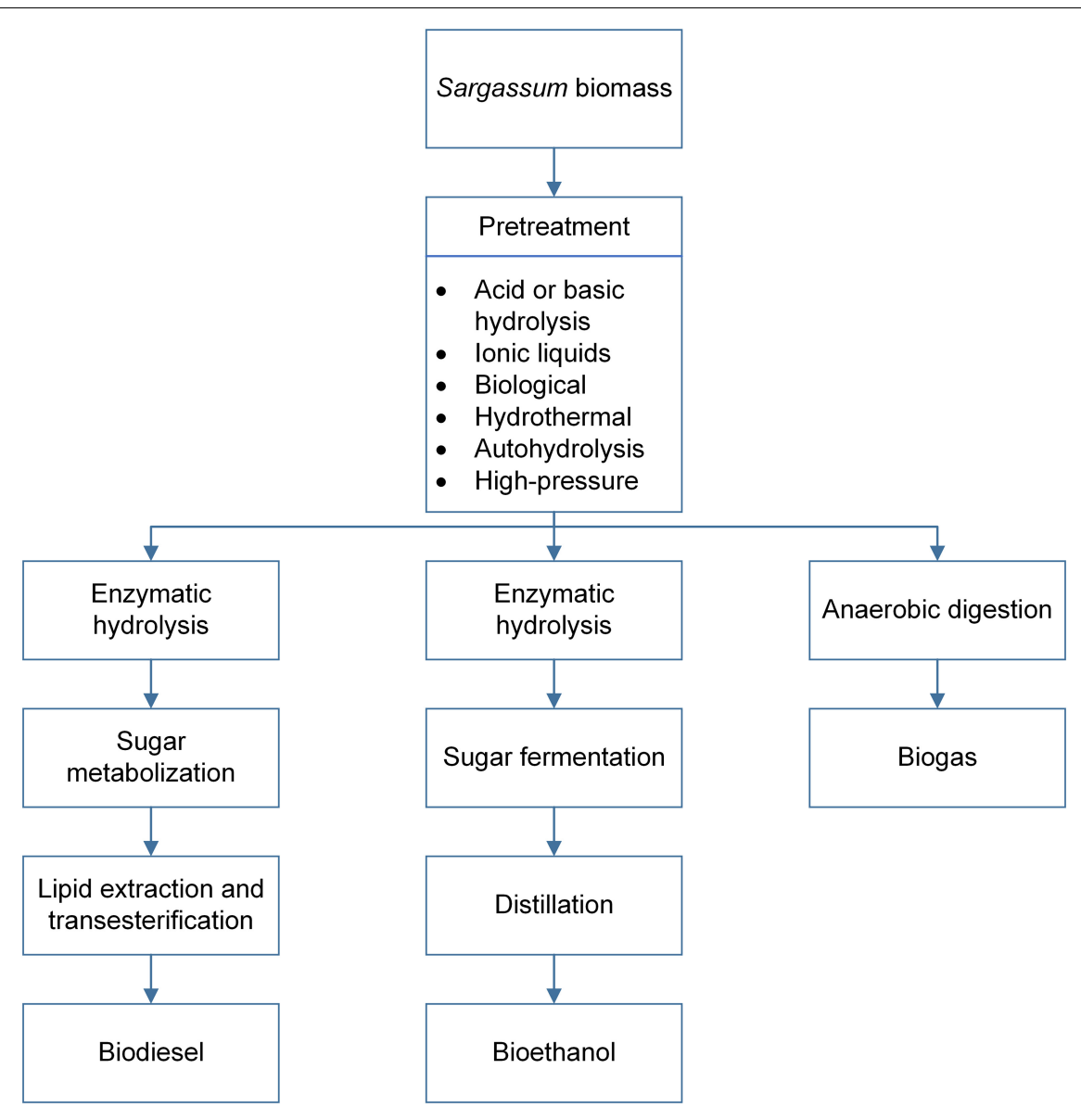

FIGURE 3 | Schematic representation for the pathways of biofuel production from pelagic Sargassum biomass.

which the microorganisms involved in the fermentation step can metabolize.

Enzymatic hydrolysis requires specific incubation temperatures, $\mathrm{pH}$ values, and residence times to function most efficaciously. The chemical composition of the treated biomass determines the proper enzymatic cocktail to be used (Aparicio et al., 2021). Some researchers have opted to couple the step of saccharification (enzymatic hydrolysis) along with fermentation and attained remarkable results. Aparicio et al. (2021) used a Pre-Simultaneous Saccharification and Fermentation (PSSF) strategy for Sargassum sp. This strategy merges the benefits of the traditional sequential hydrolysis and fermentation processing route and simultaneous saccharification and fermentation (SSF) by incorporating a pre-saccharification time before the SSF stage in previously pretreated biomass. This strategy achieved glucose to bioethanol conversion yield of $76.23 \pm 4.68 \%$ (equivalent to $18.14 \pm 1.11 \mathrm{~g} / \mathrm{L}$ of bioethanol) after 12 -h fermentation. Pre-saccharification was done using a cocktail of $B$-glucosidases, hemicellulases, and endoxylanases. Ardalan et al. (2018) showed $73 \%$ bioethanol yield from S. angustifolium in isolated hydrolysis and fermentation steps, using alginate extraction as pretreatment. This extract replaced the yeast extract in the fermentation process, and no significant difference was beheld in bioethanol yield. The pretreated Sargassum muticum via microwave hydrothermal was submitted to separate hydrolysis and fermentation, carrying-out a glucose conversion of $74 \%$ at $3 \mathrm{~h}$ hydrolysis and $96 \%$ of ethanol yield at $9 \mathrm{~h}$ of fermentation (del Río et al., 2021).

The mannose and glucose content present after enzymatic hydrolysis of the Sargassum biomass is significant in bioethanol production, as Saccharomyces cerevisiae (one of the most common yeasts used in fermentation processes) ferments these two simple sugars (Kostas et al., 2017). Of importance, the content of mannose present in Sargassum is incredibly high, as brown algae usually have high mannitol content, an alcohol polymer of the sugar mannose (Jung et al., 2013). This polysaccharide is the primary product of photosynthesis and can be easily hydrolyzed by the enzyme mannitol dehydrogenase into fructose for subsequent conversion to bioethanol (Thompson et al., 2020b). Horn et al. (2000) used the bacteria Zymobacter palmae to successfully ferment mannitol from L. hyperborea extracts into bioethanol. There is prodigious potential in the usage of pelagic Sargassum as feedstock for bioethanol and a gap in the literature as to the best microorganisms for fermenting the algal biomass. This capacity might be even greater than that 
observed for biogas production, as high levels of mannitol are undesirable for anaerobic digestion.

The ideal goal is to develop cascading bio-refineries, in which all conceivable by-products are extracted. A great example of a biorefinery scheme can be observed in a recent study by Abomohra et al. (2021), which used three different genera of seaweeds, namely Ulva sp., Gracilaria sp., and Sargassum sp., collected off the coast of the Kingdom of Saudi Arabia. The researchers concluded that Sargassum sp. has the highest copper biosorption capability, with $94.6 \%$ removal efficiency after process optimization. The team used acid hydrolysis followed by thermal treatment using steam in an autoclave at $120^{\circ} \mathrm{C}$ for $60 \mathrm{~min}$ as a pretreatment step for bioethanol production. The study reported that raw biomass had a higher biogas production yield than biomass that had absorbed copper or gone through fermentation for bioethanol production first. They also discovered, however, that biomass that had absorbed copper (bioremediation), then gone through fermentation (bioethanol production), and at last through anaerobic digestion (biogas production) had more biogas output (22.5\% more) than biomass that had just absorbed copper before being put forth as feedstock for biogas production.

\section{SARGASSUM FOR BIODIESEL PRODUCTION}

Traditionally, biodiesel production has been regarded as different from bioethanol and biogas production in that biodiesel production can be achieved directly through chemically catalyzed transesterification from oils and lipids. Therefore, feedstocks for biodiesel production require high fatty acid and lipid content. Oil from crops such as soybean, sunflower, or palm is the most abundantly used source of lipids and fatty acids for biodiesel production (Jung et al., 2013). Due to their lack of lipid content, seaweeds have not been traditionally explored as candidates for biodiesel production. Abomohra et al. (2018) determined that most seaweeds have less than $7 \%$ cellular dry weight lipid content (some reaching up to $10 \%$ cellular dry weight content). Osman et al. (2020) extracted lipids from seaweed biomass and used the remaining material for bioethanol production using Ulva intestinalis collected off the seashore of Alexandria, Egypt. They reported that lipid extraction prior to fermentation enhanced hydrolysis efficiency and sugar availability, which resulted in $14.1 \%$ higher bioethanol yield in comparison to untreated biomass that was only fermented without any lipid extraction.

Howbeit, in a more novel sense, biodiesel production can be explored via fermentation of algae with highly oleaginous organisms that can consume the simple sugars available via pretreatment methods (as described previously) and convert them to fatty acids and lipids. Another approach that has gained attention is the utilization of yeasts due to their faster growth rate and capability of valorizing the hydrolysates of lignocellulosic wastes. As an example, oleaginous strains such as Yarrowia lipolytica advantages compared to high innate lipogenesis potential (Miller and Alper, 2019). As a robust oleaginous yeast, it has been well studied to produce biofuels and other chemicals derived from fatty acids (Liu et al., 2015; Cordova et al., 2020). Additionally, it has been shown to have a high tolerance to a variety of organic compounds, elevated salt concentrations, $\mathrm{pH}$ levels, the presence of ionic liquids, heavy metals, salts, and other pollutants (aromatic, nitro, and halogenated hydrocarbons, organophosphates) making it epitome for waste valorization (Cordova et al., 2020). It is awaited that similar approaches may be feasible with high volumes of Sargassum-based biomass.

\section{GENETIC ENGINEERING AND BIOFUEL GENERATION FROM ALGAL BIOMASS}

Gathering proper enzymes without committing substantial amounts of capital is a problem in the biofuel industry, not only for macroalgae, but also for microalgae (Brar et al., 2021). Multiple metabolic processes and pathways of algae are not completely understood, and further investigation is required (Sahoo et al., 2020). Genetic engineering could pave a course for synthesizing enzymes that are specific to marine algal substrates. Metabolic engineering with the service of recombinant DNA technology could help kindle adept biofuel yields via the design of microbial biocatalysts (Konar et al., 2020).

There are some metabolic engineering strategies performed for microbial conversion of brown macroalgae (sugars of the cell wall) to ethanol. Some of the base hosts that have been used to enhance bioethanol production are Escherichia coli EPI300 (Wargacki et al., 2012), E. coli ATCC8739 (Santos et al., 2013), E. coli KO11 (Kim et al., 2020), S. cerevisiae SEY6210 (Takagi et al., 2017), S. cerevisiae BY4741 (Motone et al., 2016), and Sphingomonas sp. A1 (Takeda et al., 2011).

In the cases of Sphingomonas sp. A1 and E. coli EPI300 cultivated in alginate and Saccharina japonica, authors reached $0.26 \mathrm{~g}$ ethanol/g alginate yield and $0.28 \mathrm{~g}$ ethanol/g seaweed powder, respectively, by overexpression and improved expression of the Zymomonas mobilis genes (pdc and adhB) by an endogenous promoter (Takeda et al., 2011; Wargacki et al., 2012). The chromosomal integration of the alginate-utilizing pathway was used in E. coli ATCC8739 and was improved the productivity $(1,200 \%)$ and titer $(330 \%)$ compared its plasmid counterpart when was cultivated in a mixture of alginate, mannitol, and glucose (5:8:1 ratio) (Santos et al., 2013). A study carried out by Takagi et al. (2017) showed on the S. cerevisiae SEY6210 cell surface, endo- and exo-alginate lyases were inmobilizated from Saccharophagus degradans Alg7A and Alg7K. The obtained result was $0.15 \mathrm{~g}$ ethanol/g of mannitol and alginate mixture. Despite all the examples microbes abovementioned, the metabolic engineering applications applied to marine microbes are still limited.

\section{CONCLUDING REMARKS AND RECOMMENDATIONS}

Sargassum has the potential to be valorized into multiple exciting products. If adequate management is guaranteed for its collection 
before this biomass lands on beaches, its availability can be regarded as advantageous. Many researchers point to the use of Sargassum in the food or pharmacy industry; however, the content of dissolved metals in this algae fluctuates greatly due to the seasonal variables that influence Sargassum blooms, which ultimately can invalidate Sargassum use for these purposes. The concept of a Sargassum biorefinery makes it possible to increase the economic advantages of the current problem of massive Sargassum blooms on the beaches, being able to value intermediate products, in addition to biofuels, obtained from other components of the cell wall of the Sargassum, such as alginates and fucoidans. As to the economic feasibility of biofuel refineries, there is a dependence on a sum of factors: local transportation infrastructure, biomass availability, initial investment, among others. Success on a financial level for actors devoting resources to a Sargassum-based biorefinery is a function of further research and where the industrial complex is to be built.

Recent attempts to establish efficient solutions to mitigate the build-up of Sargassum biomass have proposed potential valorization routes that have demonstrated that pelagic Sargassum can be a competitive resource for clean energy production. The use of pelagic Sargassum as biological waste used in the production of biogas shows excellent potential and opportunity. A combination of metal nanoparticles, different cosubstrates, and ingenious feedstock pretreatments are attractive to attain the best yields. The digestate of biogas production can be used as nutrient-free fertilizer. Nevertheless, the remarkably high levels of toxic elements (e.g., arsenic) and salts present in pelagic Sargassum found in the Caribbean must be discussed in future works.

Bioethanol production from Sargassum includes operations that already exist in second and third-generation bioethanol production: pretreatment, saccharification, and fermentation. Biotechnological procedures that couple fermentations with enzymatic hydrolysis processes are an option for reducing costs. Genetic engineering could be a gateway into making necessary enzymes for increasing yields and efficiency. Finding more energy-efficient procedures and process junctures that promote economic remuneration are an excellent incentive for corporations and individuals to stake in Sargassum as a green and

\section{REFERENCES}

Abomohra, A. E.-F., El-Hefnawy, M. E., Wang, Q., Huang, J., Li, L., Tang, J., et al. (2021). Sequential bioethanol and biogas production coupled with heavy metal removal using dry seaweeds: towards enhanced economic feasibility. J. Clean. Prod. 316:128341. doi: 10.1016/j.jclepro.2021.128341

Abomohra, A. E.-F., El-Naggar, A. H., and Baeshen, A. A. (2018). Potential of macroalgae for biodiesel production: screening and evaluation studies. J. Biosci. Bioeng. 125, 231-237. doi: 10.1016/j.jbiosc.2017.08.020

Alquimar (2019). Quienes Somos. Available online at: https://alquimar.com.mx/ nosotros/ (accessed October 7, 2021).

Alzate-Gaviria, L., Domínguez-Maldonado, J., Chablé-Villacís, R., Olguin-Maciel, E., Leal-Bautista, R. M., Canché-Escamilla, G., et al. (2021). Presence of polyphenols complex aromatic "lignin" in Sargassum spp. from Mexican Caribbean. J. Mar. Sci. Eng. 9:6. doi: 10.3390/jmse9010006 renewable fuel. It is essential to point out that single-target usage of Sargassum biomass is a limited and often expensive approach.

Cascading bio-refineries, in which all possible by-products are extracted, could lead to obtaining many valuable compounds, regardless of the main process's objective. One example of this is the liquid phase residue obtained after centrifugation in bioethanol production. The liquid phase is often not used after hydrothermal pretreatment. Nonetheless, it contains an enormous amount of high added-value compounds. The future of an environmentally friendly economy depends on the usage of all possible sub-products and residues from biorefineries in an efficient manner. A significant number of studies have been done regarding converting algal biomass into biofuels. However, many researchers acknowledge that research is still at its outset and behooves further exploration to develop viable processing methodologies and technologies. While this review focuses on applications for pelagic Sargassum, macroalgae proliferation more broadly is a problem present throughout the globe.

\section{AUTHOR CONTRIBUTIONS}

JO-G and DC-N contributed to the conception of the study. JO-G and FA-C wrote the first draft of the manuscript. JO-G, DC-N, and AG-S wrote sections of the manuscript. TG-C, HA, and DC-N revised and edited the manuscript. All authors reviewed the manuscript, read and approved the submitted version.

\section{FUNDING}

This work was supported by The University of Texas System and Mexico's CONACYT (2020 ConTex Call for UT System-Conacyt Collaborative Research Grants, ConTex Grant: 2020-38B).

\section{ACKNOWLEDGMENTS}

JO-G would like to thank Tecnologico de Monterrey for academic support. FA-C would like to thank Mexico's CONACyT for scholarship funding (CVU: 104808).

Amador-Castro, F., García-Cayuela, T., Alper, H. S., Rodriguez-Martinez, V., and Carrillo-Nieves, D. (2021). Valorization of pelagic Sargassum biomass into sustainable applications: current trends and challenges. J. Environ. Manage. 283:112013. doi: 10.1016/j.jenvman.2021.112013

An, Y.-X., Li, N., Zong, M.-H., and Lou, W.-Y. (2014). Easily measurable pH as an indicator of the effectiveness of the aqueous cholinium ionic liquidbased pretreatment of lignocellulose. RSC Adv. 4, 55635-55639. doi: 10.1039/ C4RA10134K

Aparicio, E., Rodríguez-Jasso, R. M., Pinales-Márquez, C. D., Loredo-Treviño, A., Robledo-Olivo, A., Aguilar, C. N., et al. (2021). High-pressure technology for Sargassum spp biomass pretreatment and fractionation in the third generation of bioethanol production. Bioresour. Technol. 329:124935. doi: 10.1016/j. biortech.2021.124935

Ardalan, Y., Jazini, M., and Karimi, K. (2018). Sargassum angustifolium brown macroalga as a high potential substrate for alginate and ethanol production with 
minimal nutrient requirement. Algal Res. 36, 29-36. doi: 10.1016/j.algal.2018. 10.010

BBC (2019). Mexico's Top Caribbean Beaches Hit by Seaweed Infestation. BBC News. Available online at: https://www.bbc.com/news/world-latin-america- 48756500 (accessed October 7, 2021).

Borines, M. G., de Leon, R. L., and Cuello, J. L. (2013). Bioethanol production from the macroalgae Sargassum spp. Bioresour. Technol. 138, 22-29. doi: 10.1016/j. biortech.2013.03.108

Brar, A., Kumar, M., Soni, T., Vivekanand, V., and Pareek, N. (2021). Insights into the genetic and metabolic engineering approaches to enhance the competence of microalgae as biofuel resource: a review. Bioresour. Technol. 339:125597. doi: 10.1016/j.biortech.2021.125597

Chen, J., Wu, A., Yang, M., Ge, Y., Pristijono, P., Li, J., et al. (2021). Characterization of sodium alginate-based films incorporated with thymol for fresh-cut apple packaging. Food Control 126:108063. doi: 10.1016/j.foodcont.2021.108063

Cordova, L. T., Lad, B. C., Ali, S. A., Schmidt, A. J., Billing, J. M., Pomraning, K., et al. (2020). Valorizing a hydrothermal liquefaction aqueous phase through co-production of chemicals and lipids using the oleaginous yeast Yarrowia lipolytica. Bioresour. Technol. 313:123639. doi: 10.1016/j.biortech.2020.123639

Dakatso (2021). Proyecto GIS. Grupo Dakatso México. Available online at: https: //www.dakatso.com.mx/proyecto-gis/ (accessed October 7, 2021).

Davis, D., Simister, R., Campbell, S., Marston, M., Bose, S., McQueen-Mason, S. J., et al. (2021). Biomass composition of the golden tide pelagic seaweeds Sargassum fluitans and S. natans (morphotypes I and VIII) to inform valorisation pathways. Sci. Total Environ. 762:143134. doi: 10.1016/j.scitotenv. 2020.143134

del Río, P. G., Domínguez, E., Domínguez, V. D., Romaní, A., Domingues, L., and Garrote, G. (2019). Third generation bioethanol from invasive macroalgae Sargassum muticum using autohydrolysis pretreatment as first step of a biorefinery. Renew. Energy 141, 728-735. doi: 10.1016/j.renene.2019.03.083

del Río, P. G., Gullón, B., Pérez-Pérez, A., Romaní, A., and Garrote, G. (2021). Microwave hydrothermal processing of the invasive macroalgae Sargassum muticum within a green biorefinery scheme. Bioresour. Technol. 340:125733. doi: 10.1016/j.biortech.2021.125733

Fenoradosoa, T. A., Ali, G., Delattre, C., Laroche, C., Petit, E., Wadouachi, A., et al. (2010). Extraction and characterization of an alginate from the brown seaweed Sargassum turbinarioides Grunow. J. Appl. Phycol. 22, 131-137. doi: 10.1007/s10811-009-9432-y

Flórez-Fernández, N., Illera, M., Sánchez, M., Lodeiro, P., Torres, M. D., LópezMosquera, M. E., et al. (2021). Integrated valorization of Sargassum muticum in biorefineries. Chem. Eng. J. 404:125635. doi: 10.1016/j.cej.2020.125635

García-Sánchez, M., Graham, C., Vera, E., Escalante-Mancera, E., Álvarez-Filip, L., and van Tussenbroek, B. I. (2020). Temporal changes in the composition and biomass of beached pelagic Sargassum species in the Mexican Caribbean. Aquat. Bot. 167:103275. doi: 10.1016/j.aquabot.2020.103275

González-Ballesteros, N., Flórez-Fernández, N., Torres, M. D., Domínguez, H., and Rodríguez-Argüelles, M. C. (2021). Synthesis, process optimization and characterization of gold nanoparticles using crude fucoidan from the invasive brown seaweed Sargassum muticum. Algal Res. 58:102377. doi: 10.1016/j.algal. 2021.102377

Gouvêa, L. P., Assis, J., Gurgel, C. F. D., Serrão, E. A., Silveira, T. C. L., Santos, R., et al. (2020). Golden carbon of Sargassum forests revealed as an opportunity for climate change mitigation. Sci. Total Environ. 729:138745. doi: 10.1016/j. scitotenv.2020.138745

Hasnain, M. S., Jameel, E., Mohanta, B., Dhara, A. K., Alkahtani, S., and Nayak, A. K. (2020). "Alginates: sources, structure, and properties," in Alginates in Drug Delivery, eds A. K. Nayak and M. S. Hasnain (Amsterdam: Elsevier), 1-17. doi: 10.1016/B978-0-12-817640-5.00001-7

Horn, S. J., Aasen, I. M., and Østgaard, K. (2000). Production of ethanol from mannitol by Zymobacter palmae. J. Ind. Microbiol. Biotechnol. 24, 51-57. doi: 10.1038/sj.jim.2900771

John, R. P., Anisha, G. S., Nampoothiri, K. M., and Pandey, A. (2011). Micro and macroalgal biomass: a renewable source for bioethanol. Bioresour. Technol. 102, 186-193. doi: 10.1016/j.biortech.2010.06.139

Johns, E. M., Lumpkin, R., Putman, N. F., Smith, R. H., Muller-Karger, F. E., RuedaRoa, D. T., et al. (2020). The establishment of a pelagic Sargassum population in the tropical Atlantic: biological consequences of a basin-scale long distance dispersal event. Prog. Oceanogr. 182:102269. doi: 10.1016/j.pocean.2020.102269
Jung, K. A., Lim, S.-R., Kim, Y., and Park, J. M. (2013). Potentials of macroalgae as feedstocks for biorefinery. Bioresour. Technol. 135, 182-190. doi: 10.1016/j. biortech.2012.10.025

Kim, D. H., Liu, J.-J., Lee, J. W., Pelton, J. G., Yun, E. J., Yu, S., et al. (2020). Biological upgrading of 3,6-anhydro- L -galactose from agarose to a new platform chemical. Green Chem. 22, 1776-1785. doi: 10.1039/C9GC04265B

Kim, S.-S., Ly, H. V., Kim, J., Choi, J. H., and Woo, H. C. (2013). Thermogravimetric characteristics and pyrolysis kinetics of Alga Sagarssum sp. biomass. Bioresour. Technol. 139, 242-248. doi: 10.1016/j.biortech.2013.03.192

Konar, D., Saha, R., Bhattacharya, D., and Mukhopadhyay, M. (2020). "Present status and future prospect of genetic and metabolic engineering for biofuels from lignocellulosic biomass," in Genetic and Metabolic Engineering for Improved Biofuel Production from Lignocellulosic Biomass, eds A. Kuila and V. Sharma (Amsterdam: Elsevier), 37-46. doi: 10.1016/B978-0-12-817953-6. 00003-8

Kostas, E. T., White, D. A., and Cook, D. J. (2017). Development of a biorefinery process for the production of speciality chemical, biofuel and bioactive compounds from Laminaria digitata. Algal Res. 28, 211-219. doi: 10.1016/j. algal.2017.10.022

Liu, L., Pan, A., Spofford, C., Zhou, N., and Alper, H. S. (2015). An evolutionary metabolic engineering approach for enhancing lipogenesis in Yarrowia lipolytica. Metab. Eng. 29, 36-45. doi: 10.1016/j.ymben.2015.02.003

Malihan, L. B., Nisola, G. M., and Chung, W.-J. (2012). Brown algae hydrolysis in 1-n-butyl-3-methylimidazolium chloride with mineral acid catalyst system. Bioresour. Technol. 118, 545-552. doi: 10.1016/j.biortech.2012.05.091

Milledge, J., and Harvey, P. (2016). Golden tides: problem or golden opportunity? The valorisation of Sargassum from beach inundations. J. Mar. Sci. Eng. 4:60. doi: $10.3390 /$ jmse 4030060

Miller, K. K., and Alper, H. S. (2019). Yarrowia lipolytica: more than an oleaginous workhorse. Appl. Microbiol. Biotechnol. 103, 9251-9262. doi: 10.1007/s00253019-10200-x

Mohammed, A., Rivers, A., Stuckey, D. C., and Ward, K. (2020). Alginate extraction from Sargassum seaweed in the Caribbean region: optimization using response surface methodology. Carbohydr. Polym. 245:116419. doi: 10.1016/j. carbpol.2020.116419

Monroy-Velázquez, L. V., Rodríguez-Martínez, R. E., van Tussenbroek, B. I., Aguiar, T., Solís-Weiss, V., and Briones-Fourzán, P. (2019). Motile macrofauna associated with pelagic Sargassum in a Mexican reef lagoon. J. Environ. Manage. 252:109650. doi: 10.1016/j.jenvman.2019.109650

Montingelli, M. E., Tedesco, S., and Olabi, A. G. (2015). Biogas production from algal biomass: a review. Renew. Sustain. Energy Rev. 43, 961-972. doi: 10.1016/ j.rser.2014.11.052

Motone, K., Takagi, T., Sasaki, Y., Kuroda, K., and Ueda, M. (2016). Direct ethanol fermentation of the algal storage polysaccharide laminarin with an optimized combination of engineered yeasts. J. Biotechnol. 231, 129-135. doi: 10.1016/j. jbiotec.2016.06.002

Moura, J. C. M. S., Bonine, C. A. V., De Oliveira Fernandes Viana, J., Dornelas, M. C., and Mazzafera, P. (2010). Abiotic and biotic stresses and changes in the lignin content and composition in plants. J. Integr. Plant Biol. 52, 360-376. doi: 10.1111/j.1744-7909.2010.00892.x

Oliveira, J. V., Alves, M. M., and Costa, J. C. (2015). Optimization of biogas production from Sargassum sp. using a design of experiments to assess the codigestion with glycerol and waste frying oil. Bioresour. Technol. 175, 480-485. doi: 10.1016/j.biortech.2014.10.121

Osman, M. E. H., Abo-Shady, A. M., Elshobary, M. E., Abd El-Ghafar, M. O., and Abomohra, A. E.-F. (2020). Screening of seaweeds for sustainable biofuel recovery through sequential biodiesel and bioethanol production. Environ. Sci. Pollut. Res. 27, 32481-32493. doi: 10.1007/s11356-020-09534-1

Ravanal, M. C., Pezoa-Conte, R., von Schoultz, S., Hemming, J., Salazar, O., Anugwom, I., et al. (2016). Comparison of different types of pretreatment and enzymatic saccharification of Macrocystis pyrifera for the production of biofuel. Algal Res. 13, 141-147. doi: 10.1016/j.algal.2015.11.023

Rostro, M., Sánchez-González, M., Rivas, S., Moure, A., Domínguez, H., and Parajó, J. C. (2014). Non-isothermal autohydrolysis of nixtamalized maize pericarp: production of nutraceutical extracts. LWT Food Sci. Technol. 58, 550-556. doi: 10.1016/j.lwt.2014.03.043

Sahoo, S., Mahapatra, S. R., Das, N., Parida, B. K., Rath, S., Misra, N., et al. (2020). Functional elucidation of hypothetical proteins associated with lipid 
accumulation: prioritizing genetic engineering targets for improved algal biofuel production. Algal Res. 47:101887. doi: 10.1016/j.algal.2020.101887

Saldarriaga-Hernandez, S., Melchor-Martínez, E. M., Carrillo-Nieves, D., ParraSaldívar, R., and Iqbal, H. M. N. (2021). Seasonal characterization and quantification of biomolecules from Sargassum collected from Mexican Caribbean coast - A preliminary study as a step forward to blue economy. J. Environ. Manage. 298:113507. doi: 10.1016/j.jenvman.2021.11 3507

Santos, C. N. S., Regitsky, D. D., and Yoshikuni, Y. (2013). Implementation of stable and complex biological systems through recombinase-assisted genome engineering. Nat. Commun. 4:2503. doi: 10.1038/ncomms3503

Savage, E., Nagle, N., Laurens, L. M. L., and Knoshaug, E. P. (2020). Nitrogen derived from combined algal processing supports algae cultivation for biofuels. Algal Res. 50:101987. doi: 10.1016/j.algal.2020.101987

Serebryakova, A., Aires, T., Viard, F., Serrão, E. A., and Engelen, A. H. (2018). Summer shifts of bacterial communities associated with the invasive brown seaweed Sargassum muticum are location and tissue dependent. PLoS One 13:e0206734. doi: 10.1371/journal.pone.0206734

Siddiki, S. Y. A., Mofijur, M., Kumar, P. S., Ahmed, S. F., Inayat, A., Kusumo, F., et al. (2022). Microalgae biomass as a sustainable source for biofuel, biochemical and biobased value-added products: an integrated biorefinery concept. Fuel 307:121782. doi: 10.1016/j.fuel.2021.121782

Sun, Q.-L., Li, Y., Ni, L.-Q., Li, Y.-X., Cui, Y.-S., Jiang, S.-L., et al. (2020). Structural characterization and antiviral activity of two fucoidans from the brown algae Sargassum henslowianum. Carbohydr. Polym. 229:115487. doi: 10.1016/j.carbpol.2019.115487

Tadesse, H., and Luque, R. (2011). Advances on biomass pretreatment using ionic liquids: an overview. Energy Environ. Sci. 4, 3913-3929. doi: 10.1039/ C0EE00667J

Takagi, T., Sasaki, Y., Motone, K., Shibata, T., Tanaka, R., Miyake, H., et al. (2017). Construction of bioengineered yeast platform for direct bioethanol production from alginate and mannitol. Appl. Microbiol. Biotechnol. 101, 6627-6636. doi: 10.1007/s00253-017-8418-y

Takeda, H., Yoneyama, F., Kawai, S., Hashimoto, W., and Murata, K. (2011). Bioethanol production from marine biomass alginate by metabolically engineered bacteria. Energy Environ. Sci. 4:2575. doi: 10.1039/clee01236c

Tapia-Tussell, R., Avila-Arias, J., Domínguez Maldonado, J., Valero, D., OlguinMaciel, E., Pérez-Brito, D., et al. (2018). Biological pretreatment of Mexican Caribbean Macroalgae consortiums using Bm-2 Strain (Trametes hirsuta) and its enzymatic broth to improve biomethane potential. Energies 11:494. doi: 10.3390/en 11030494

Tarchoun, A. F., Trache, D., and Klapötke, T. M. (2019). Microcrystalline cellulose from Posidonia oceanica brown algae: extraction and characterization. Int. J. Biol. Macromol. 138, 837-845. doi: 10.1016/j.ijbiomac.2019.07.176

Thompson, T. M., Young, B. R., and Baroutian, S. (2019). Advances in the pretreatment of brown macroalgae for biogas production. Fuel Process. Technol. 195:106151. doi: 10.1016/j.fuproc.2019.106151
Thompson, T. M., Young, B. R., and Baroutian, S. (2020a). Efficiency of hydrothermal pretreatment on the anaerobic digestion of pelagic Sargassum for biogas and fertiliser recovery. Fuel 279:118527. doi: 10.1016/j.fuel.2020. 118527

Thompson, T. M., Young, B. R., and Baroutian, S. (2020b). Pelagic Sargassum for energy and fertiliser production in the Caribbean: a case study on Barbados. Renew. Sustain. Energy Rev. 118:109564. doi: 10.1016/j.rser.2019.109564

Thompson, T. M., Young, B. R., and Baroutian, S. (2021). Enhancing biogas production from Caribbean pelagic Sargassum utilising hydrothermal pretreatment and anaerobic co-digestion with food waste. Chemosphere 275:130035. doi: 10.1016/j.chemosphere.2021.130035

Wang, M., and Hu, C. (2016). Mapping and quantifying Sargassum distribution and coverage in the Central West Atlantic using MODIS observations. Remote Sens. Environ. 183, 350-367. doi: 10.1016/j.rse.2016.04.019

Wargacki, A. J., Leonard, E., Win, M. N., Regitsky, D. D., Santos, C. N. S., Kim, P. B., et al. (2012). An Engineered microbial platform for direct biofuel production from brown macroalgae. Science 335, 308-313. doi: 10.1126/science.1214547

Xue, S., Wang, Y., Lyu, X., Zhao, N., Song, J., Wang, X., et al. (2020). Interactive effects of carbohydrate, lipid, protein composition and carbon/nitrogen ratio on biogas production of different food wastes. Bioresour. Technol. 312:123566. doi: 10.1016/j.biortech.2020.123566

Yuhendra, A. P., Farghali, M., Mohamed, I. M. A., Iwasaki, M., Tangtaweewipat, S., Ihara, I., et al. (2021). Potential of biogas production from the anaerobic digestion of Sargassum fulvellum macroalgae: influences of mechanical, chemical, and biological pretreatments. Biochem. Eng. J. 175, 108140. doi: 10. 1016/j.bej.2021.108140

Zaidi, A. A., Khan, S. Z., and Shi, Y. (2021). Optimization of nickel nanoparticles concentration for biogas enhancement from green algae anaerobic digestion. Mater. Today Proc. 39, 1025-1028. doi: 10.1016/j.matpr.2020.04.762

Conflict of Interest: The authors declare that the research was conducted in the absence of any commercial or financial relationships that could be construed as a potential conflict of interest.

Publisher's Note: All claims expressed in this article are solely those of the authors and do not necessarily represent those of their affiliated organizations, or those of the publisher, the editors and the reviewers. Any product that may be evaluated in this article, or claim that may be made by its manufacturer, is not guaranteed or endorsed by the publisher.

Copyright (c) 2022 Orozco-González, Amador-Castro, Gordillo-Sierra, GarcíaCayuela, Alper and Carrillo-Nieves. This is an open-access article distributed under the terms of the Creative Commons Attribution License (CC BY). The use, distribution or reproduction in other forums is permitted, provided the original author(s) and the copyright owner(s) are credited and that the original publication in this journal is cited, in accordance with accepted academic practice. No use, distribution or reproduction is permitted which does not comply with these terms. 